\title{
HEALING HOME
}

\section{Health and Homelessness in the Life Stories of Young Women}

Based on research that was awarded the Governor General's Academic Gold Medal, Healing Home is an exploration of the lives and health of young women experiencing homelessness. Vanessa Oliver employs an innovative methodology that blends sociology and storytelling practices to investigate these women's access to health services, their understandings of health and health care delivery, and their health-seeking behaviours. Through their life stories, Oliver demonstrates how personal and social experiences shape health outcomes.

In contrast to many previous studies that have focused on the deficits of these young people, Healing Home is both youth-centric and youth-positive in its approach: by foregrounding the narratives of the women themselves, Oliver empowers a sub-section of the population that traditionally has not had a voice in determining policies that shape their realities. Applying a strong, articulate, and systemic analysis to on-the-ground narratives, Oliver is able to offer fresh, incisive recommendations for health and social service providers with the potential to effect real-world change for this marginalized population.

VANESSA OLIVER is an assistant professor in the Department of Sociology at Mount Allison University. 
This page intentionally left blank 


\section{Healing Home}

Health and Homelessness in

the Life Stories of Young Women

VANESSA OLIVER

UNIVERSITY OF TORONTO PRESS

Toronto Buffalo London 
(C) University of Toronto Press 2013

Toronto Buffalo London

www.utppublishing.com

Printed in Canada

ISBN 978-1-4426-4531-8 (cloth)

ISBN 978-1-4426-1344-7 (paper)

(2)

Printed on acid-free, $100 \%$ post-consumer recycled paper with vegetablebased inks.

\section{Library and Archives Canada Cataloguing in Publication}

Oliver, Vanessa, 1980-

Healing home : health and homelessness in the life stories of young women / Vanessa Oliver

Includes bibliographical references and index.

ISBN 978-1-4426-4531-8 (bound) - ISBN 978-1-4426-1344-7 (pbk.)

1. Homelessness - Health aspects - Ontario - Toronto - Case studies.

2. Homeless women - Ontario - Toronto - Case studies. 3. Homeless women - Ontario - Toronto - Biography. 4. Women - Health and hygiene - Ontario - Toronto - Case studies. 5. Health services accessibility - Ontario - Toronto - Case studies. 6. Toronto (Ont.) - Social conditions - 21st century - Case studies. I. Title.

RA564.9.H63O45 2013 362.1'0425 C2012-906819-5

University of Toronto Press acknowledges the financial assistance to its publishing program of the Canada Council for the Arts and the Ontario Arts Council.

Canada Council Conseil des Arts for the Arts

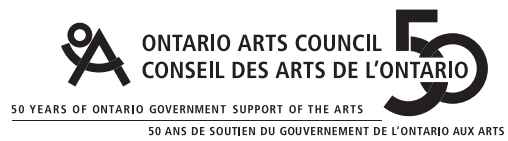

University of Toronto Press acknowledges the financial support of the Government of Canada through the Canada Book Fund for its publishing activities. 
To my mothers

Susan Phillips Oliver

$\mathcal{E}$

Nellie Green Oliver

Who taught me the most valuable things I know:

Love

Compassion

Determination 
This page intentionally left blank 